\title{
Pakettipellot, niiden käyttö ja hoito Keski-Suomessa vuonna 1974
}

\author{
HEIKKI HOKKANEN \\ Jyväskylän yliopisto, Biologian laitos, Yliopistonkatu 9, 40100 Jyväskylä 10
}

\section{Reserved fields, their use and management in central Finland in 1974}

\author{
HEIKKI HOKKANEN \\ University of Jyväskylä, Department of Biology, Yliopistonkatu 9, 40100 Jyväskylä 10
}

\begin{abstract}
Information about the properties of reserved farms, their fields, and the use and management of the fields was obtained with questionnaires covering 671 reserved fields on 297 farms in Central Finland.

Reserved farms resemble closely the productive farms of the study area, the biggest difference being the smaller field area in reserved farms. Their fields are usually small in size, median 2.0 ha, open ditched $(88 \%)$ or without ditches $(10 \%)$, and reserved after ley $(55 \%)$ or spring cereals $(34 \%)$. Most fields are situated separately, the median distance to the main building is $80 \mathrm{~m}$, to a public road $200 \mathrm{~m}$, and to a water area $500 \mathrm{~m}$. $57 \%$ of them are in visible contact with no more than one house. Half of the fields are in no contact with other fields; in about $10 \%$ of the cases the size of the clearance is over 20 ha.

In $197492 \%$ of the farms were inhabited for at least a part of the year. Half of the fields were used for some purpose: $23 \%$ had been afforested, $19 \%$ were used for growing potato and root vegetables, and about $6 \%$ were grazed by sheep or horse.

The afforested fields were mostly small in size and situated far away from the main building and roads. Others were closer to farms with also other activities, and to fields with a favourable location.

More than half of the fields were unmanaged in 1974 . $33 \%$ were mowed, $7 \%$ ploughed, and some fields were burnt or treated with herbicides. $20 \%$ of the fields had at times been sown for ley during the reservation. As to weed dispersal, management activities were generally poorly timed. They were, however, quite correctly concentrated onto the largest fields and to fields adjacent to other fields and to fields visible in the landscape.
\end{abstract}

\section{Johdanto}

Maatalouden ylituotanto-ongelmien helpottamiseksi ryhdyttiin vuonna 1969 maksamaan palkkioita niille viljelijöille, jotka pidättäytyivät maansa viljelemisestä. Sopimus pellon käytön rajoittamisesta voitiin tehdä korkeintaan 
kolmeksi kolmivuotiskaudeksi, ja viimeiset uudet sopimukset solmittiin vuonna 1974. Järjestelmän piiriin on maamme peltoalasta kuulunut lähes $9 \%$ (ANoN. 1975).

Vuosina 1969-1974 solmittiin Keski-Suomessa 3091 sopimusta yhteensä 18819 peltohehtaarin paketoinnista (Anon. 1976). Vuoden 1978 alussa niistä oli voimassa vielä $2230 \mathrm{kpl}$, vastaten 13042 ha:n varausaluetta (Jyväskylän Maatalouspiiri, suullinen tiedonanto). Maakunnan tilaluvusta järjestelmä on käsittänyt noin $18 \%$ ja peltoalasta noin $14 \%$ (ANoN. 1975).

Pellonvarauslain $(216 / 69$ ja $19 / 70)$ ja -asetuksen $(217 / 69$ ja 68/70) mukaan sopimuksenalaisia peltoja on hoidettava siten, etteivät ne rikkaruohotu siinä määrin, että siitä olisi haittaa ympäristön viljelyksille. Samaten viljelijän on estettävä korvauksen alaisen pellon haitallinen vesottuminen. Hoitovelvoitteen täyttämisen seuraamiseksi ainakin muihin viljelyksiin rajoittuvat pakettipellot tarkastetaan kerran vuodessa maatalouden piiriorganisaation toimesta.

Tämän tutkimuksen tarkoituksena on ollut selvittää miten ja missä laajuudessa pakettipeltoja Keski-Suomessa käytetään ja hoidetaan, ja miten ne suhtautuvat toisaalta annettuihin määräyksiin ja toisaalta pelloilla tapahtuvaan ekologiseen suksessioon.

Pellonvaraustoimintaa ja sen vaikutuksia on maassamme tutkittu melko aktiivisesti. Selvitysten lähestymistavat ovat pääasiassa olleet aluemaantieteellis - sosiologisia (mm. JaAtinen ja KärkKärnen 1971, JaAtinen ja NygÅrd 1973, Juntunen 1978) ja ekologis - luonnonhoidollisia (mm. Törmälä ja RaAtikainen 1976, Hokkanen ja RaAtikainen 1977, 1978, Törmälä 1977).

\section{Tutkimusaineiston kokoaminen}

Tämän tutkimuksen aineisto on kerätty kyselylomakkeilla talvella 1975 Keski-Suomen alueen pellonvaraustiloilta. Kunnittain suoritetulla ositeotannalla valittiin 350 yksityisten omistamaa tilaa kyselyn kohteiksi. Vastaustiedot saatiin 276 tilalta; 15 lomaketta palautettiin tyhjänä, koska vastaanottajaa ei ollut tavattu. Yhteisöjen omistamilta pakettipeltotiloilta (33 tilaa) tiedot saatiin 21 tilalta. Näin aineisto käsittää tiedot 297 pakettipeltotilan yhteensä 671 peltopalstalta (vastausprosentti 81).

\section{Tilojen taustatiedot}

Keskisuomalainen pakettipeltotila on suhteellisen pienikokoinen, kokonaispinta-ala tutkimustiloilla oli keskimäärin 39.7 ha (mediaani 29.0 ha). Tästä metsämaan osuus oli 30.4 ha ja peltomaan 6.0 ha. Luvut eivät kovin paljoa poikkea Keski-Suomen maatilojen keskimääräisistä pinta-aloista (metsää 36.5 ha ja peltoa 7.3 ha, Anov. 1975), mutta esimerkiksi Pohjois-Pohjanmaalla pakettipeltotilojen kokonaispinta-alan mediaani on 72.8 ha (JUNTUNEN 1978). Seuraavassa vertaillaan tutkimustilojen ja Keski-Suomen kaikkien yli 2 peltohehtaarin maatilojen lukumäärien prosentuaalista jakautumista eri kokoluokkiin metsäpinta-alan mukaan ( $\mathrm{n}=$ tilojen lukumäärä, joilta kyseinen tieto on saatu): 
metsäala (ha)

$\%$ tiloista

pellonvaraustilat $(\mathrm{n}=252)$

$<5 \quad 5-10$

$10-20$

$20-50$

$50-100>10 \mathrm{C}$

kaikki maatilat (ANoN. 1975)

$\begin{array}{llllll}7.5 & 7.5 & 31.4 & 37.7 & 12.7 & 3.3 \\ 7.5 & 7.4 & 22.3 & 39.4 & 16.0 & 7.4\end{array}$

Ero metsäaloissa varsinkin pienissä kokoluokissa on mitätön; sen sijaan tilan peltopinta-ala pellonvaraustiloilla oli huomattavasti pienempi kuin alueen maatiloilla (yli 2 peltohehtaarin tilat v. 1973, ANoN. 1976) keskimäärin:

$\%$ tiloista

pellonvaraustilat $(\mathrm{n}=293)$

kaikki maatilat peltoala (ha)

$\begin{array}{lrrr}2-5 & 5-10 & 10-20 & >20 \\ 52.6 & 34.8 & 12.3 & 0.3 \\ 33.9 & 40.7 & 21.0 & 4.4\end{array}$

Yli puolella pellonvaraustiloista peltoala oli alle 5 ha (mediaani $4.7 \mathrm{ha}$ ), kun taas alueen kaikista maatiloista tässä kokoluokassa on vain kolmannes. Tilojen peltoala oli lähes kokonaan korvauksen alaista pinta-alaa, paketoitu peltoala oli keskimäärin 5.7 ha (mediaani 4.7 ha).

Tutkimuksessa määriteltiin peltolohko (peltopalsta) tarkoittamaan tilaan kuuluvia erillisiä peltokuvioita, jotka eivät kosketa toisiaan. Näitä tiloilla oli keskimäärin $2.3 \mathrm{kpl}$, suurin ilmoitettu palstojen lukumäärä oli $8 \mathrm{kpl} /$ tila. Yli kolmasosalla tiloista oli kuitenkin vain yksi peltopalsta. Tässä käytetty palstakäsite vastannee myös yleisesti käytössä olevaa peltopalstan käsitettä. Peltopalstoja on pohjoisessa Keski-Suomessa keskimäärin $2.6 \mathrm{kpl} /$ tila (ANoN. 1974) ja Keski-Suomen parhailla viljelysalueilla Laukaassa $1.8 \mathrm{kpl} /$ tila (ANon. 1972).

Paketoimisaktiivisuus eri vuosina noudatteli tutkimusalueella melko tarkasti koko maan keskiarvoja, lähtien kuitenkin liikkeelle hieman hitaammin ja jatkuen sitten vähän keskimääräistä innokkaampana viimeisinä vuosina:

paketoimisvuosi

$\%$ tiloista

1969

1970

1971

1972

1973

1974

tutkimustilat $(\mathrm{n}=297) \quad \ldots \ldots \ldots \ldots \ldots, \quad 31.8$

37.2

21.8

11.9

12.3

19.5

2.7

koko maa

20.5

13.7

12.4

13.3

3.1

(JUNTUNEN 1978)

\section{Peltopalstojen ominaisuudet ja sijainti}

Pakettipeltopalstojen keskikoko oli 2.5 ha (mediaani 2.0 ha). Tämä on melko lähellä pohjoisen Keski-Suomen peltopalstojen keskikokoa, mutta vähemmän kuin puolet Laukaan arvosta (5.5 ha) (Anon. 1972 ja 1974). Palstat jakautuivat kokoluokkiin seuraavasti:

\begin{tabular}{ccccccc}
\multicolumn{2}{c}{ pinta-ala (ha) } & & & & \\
& $<0.5$ & $0.5-1$ & $1-2$ & $2-5$ & $5-10$ & $>10$ \\
p palstoista $(\mathrm{n}=662)$ & 6.7 & 15.6 & 27.6 & 38.7 & 9.5 & 2.0
\end{tabular}


Valtaosa tutkimuspalstoista oli varustettu avo-ojin, $87.9 \%$. Ojittamattomia oli $10.0 \%$ ja salaojitettuja $2.0 \%$ palstoista. Salaojitettuja peltoja on paketoitu suhteellisestikin huomattavasti vähemmän kuin muita peltoja, sillä koko läänin peltoalasta on salaojitettu $10.3 \%$ (Anov. 1976) ja pohjoisessa KeskiSuomessakin 5.6\% (AnoN. 1974).

Palstan käytöstä paketointia edeltäneenä vuotena annettiin kyselyssä vaikeasti tulkittavia vastauksia, sillä usein oli ruksattu kaikki esitetyt vaihtoehdot. Palstojen viljelyshistoria näyttää näin olevan hyvin epäyhtenäinen ja samalla palstalla on ilmeisesti ollut useammanlaista käyttöä. Vastausten jakauma muodostui seuraavaksi:

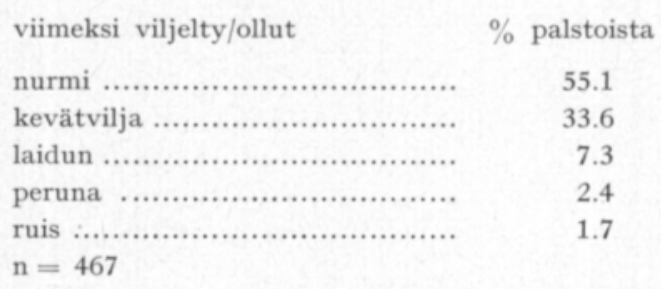

Pääkomponenttien osalta jakauma noudattelee hyvin Keski-Suomen peltojen maankäyttömuotoja vuonna 1969 (ks. Anon. 1975).

Pakettipeltopalstat Keski-Suomessa sijaitsevat keskimäärin 400 metrin päässä päärakennuksesta (mediaani $80 \mathrm{~m}$ ), 550 metrin päässä yleisestä maantiestä (mediaani $200 \mathrm{~m}$ ) ja 830 metrin päässä vesialueesta (mediaani $500 \mathrm{~m}$ ); sijaintijakaumat ko. parametrien suhteen olivat:

\begin{tabular}{|c|c|c|c|}
\hline palstan etäisyys (m) & $\begin{array}{l}\% \text { palstoista } \\
\text { päärakennuksesta }\end{array}$ & maantiestä & vesialueesta \\
\hline $0-5 \ldots \ldots \ldots \ldots$ & 13.9 & 25.8 & 11.4 \\
\hline 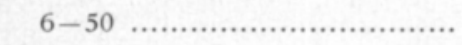 & 33.9 & 12.7 & 14.8 \\
\hline 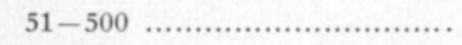 & 34.4 & 34.8 & 28.6 \\
\hline 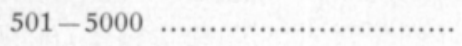 & 17.1 & 25.0 & 44.5 \\
\hline 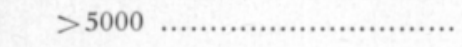 & 0.7 & 1.7 & 0.7 \\
\hline n $\ldots \ldots \ldots \ldots \ldots \ldots$ & 604 & 597 & 569 \\
\hline
\end{tabular}

Palstojen etäisyys päärakennuksesta on lähes sama kun kaikilla tiloilla keskimäärin Laukaassa (420 m, Anon. 1972), mutta pohjoisessa Keski-Suomessa palstat sijaitsevat keskimäärin huomattavasti kauempana talouskeskuksesta (keskietäisyys $800 \mathrm{~m}$, Anon. 1974). Se, että pakettipeltotiloilla palstat sijaitsevat keskimäärin lähempänä päärakennusta kuin muilla tiloilla, johtunee mm. pienemmästä tilakohtaisesta peltoalasta ja palstalukumäärästä.

Pakettipellot sijaitsevat useimmiten suhteellisen syrjässä asutuksesta ja yleisistä liikenneväylistä. Niinpä $28.5 \%$ palstoista ei näy ollenkaan asumuksiin, ja korkeintaan yhteen asumukseen näkyy $\mathbf{5 6 . 5} \%$. Joka kymmenes palsta näkyy useampaan kuin viiteen asumukseen. Yleisesti käytössä olevalle maantielle palstoista näkyy $45.7 \%$ ja vesialueelle vajaa kolmannes, $31.4 \%$. 
Palstojen liittymistä muihin viljelyksiin mitattiin vähentämällä ilmoitetusta peltoaukean koosta palstan pinta-ala. Näin saatu ala jakautui kokoluokkiin seuraavasti:

$\%$ palstoista $(\mathrm{n}=525)$

\begin{tabular}{|c|c|c|}
\hline$<0.5$ & $0.5-5$ & $5-20$ \\
\hline 51.1 & 26.5 & 12.4 \\
\hline
\end{tabular}

Keski-Suomessa yli puolet pakettipeltopalstoista sijaitsee siis erillään muista viljelyksistä, mutta esim. Pohjois-Pohjanmaalla n. $70 \%$ rajoittuu toisen tilan peltoihin (JUNTUNEN 1978). Tästä johtuen pakettipeltojen hoitoon liittyvät kysymykset koskevat korostetusti mm. Pohjanmaata ja muita alueita, missä pellot muodostavat suuria yhtenäisiä viljelyaukeita.

\section{Tilojen ja palstojen käyttö}

Tutkimustiloista asuttin $78.9 \%: 11$ a vakituisesti kautta vuoden. Pelkästään kesänviettopaikkana käytettiin lisäksi $12.8 \%$ tiloista, joten asuttuna oli ainakin osan vuotta kaikkiaan $91.7 \%$ tiloista. Asutuista tiloista $93.7 \%$ oli ollut pelkästään omistajan omassa käytössä, $1.6 \%$ oli ollut kokonaan vuokrattuna ulkopuolisille, ja sekä isäntäväen että vuokralaisten käytössä oli ollut $4.7 \%$ tiloista.

Pellonvarauslain mukaan sopimuksen tehneellä viljelijällä on edelleen oikeus käyttää peltojaan usealla eri tavalla. Hän saa mm. tuottaa perunaa sekä puutarha- ja kasvitarhatuotteita oman perheen kulutukseen. Hedelmien ja marjojen viljely on sallittu rajoituksetta. Pelloilla saa myös laiduntaa hevosia, poroja, vuohia ja lampaita, sekä harjoittaa mehiläisten hoitoa ja turkistarhausta. Samaten voi pelloilta korjata heinää em. eläinten talvirehuksi ja kuivikkeiksi. Peltoja voi myös käyttää riistapeltoina tai ne voidaan eri hakemuksesta metsittää. Keski-Suomen pakettipeltotiloilla näitä mahdollisuuksia on käytetty hyväksi vähän, ainoastaan metsitys, kotitarveperunan ja -juurikasvien viljely sekä laiduntaminen olivat merkittävässä määrin yleisiä käyttömuotoja.

Palstojen selväpiirteisin yhtenäinen käyttömuoto oli metsitys, $22.5 \%$ $(151 \mathrm{kpl})$ niistä oli metsitetty. Lajistollinen jakauma palstoilla oli:

\begin{tabular}{|c|c|}
\hline $1 \mathrm{a} \mathrm{j} \mathrm{i} \mathrm{(t)}$ & $\begin{array}{c}\%: \text { Ila kaikista } \\
\text { palstoista }\end{array}$ \\
\hline pelkästään koivu ...................... & 7.9 \\
\hline mänty .................. & 6.0 \\
\hline kuusi ....................... & 3.9 \\
\hline mänty ja koivu ......................... & 2.2 \\
\hline mänty, koivu ja kuusi .............. & 1.2 \\
\hline mänty ja kuusi ......................... & 0.8 \\
\hline kuusi ja koivu .......................... & 0.6 \\
\hline 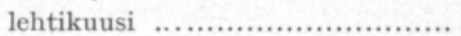 & 0.2 \\
\hline
\end{tabular}


Suurin osa metsitetyistä palstoista oli metsitetty paketointia seuraavana vuotena, metsitysviive vuosina paketoinnin jälkeen oli:

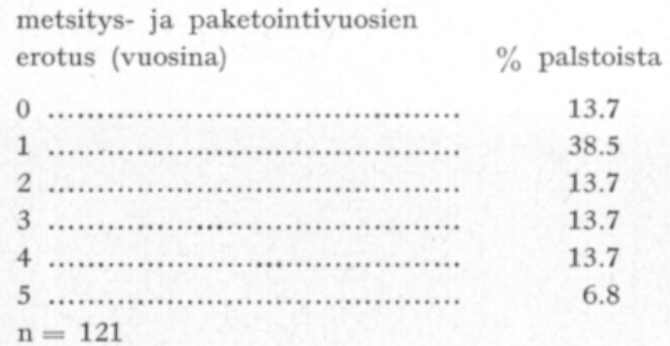

Toinen lähes yhtä selväpiirteinen käyttömuoto oli kotitarveperunan ja muiden juurikasvien viljely, yhteensa $18.7 \%$ :lla palstoista. Laiduntamiseen käytettiin $6.1 \%$ palstoista. Hevoslaitumena oli $4.2 \%$ ja lammaslaitumena $1.6 \%$ palstoista, lisäksi ilmoitettiin kahdella palstalla $(0.3 \%)$ olleen lypsykarjaa. Yhteenveto kaikkien ilmoitettujen käyttömuotojen osuuksista esitetään seuraavassa asetelmassa:

\begin{tabular}{|c|c|}
\hline käyttömuoto & $\%$ palstoista \\
\hline metsitys . & 22.5 \\
\hline perunan ja juurikasvien viljely. & 18.7 \\
\hline 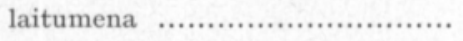 & 6.1 \\
\hline riistapeltona ................ & 2.7 \\
\hline talvirehun ottopaikkana ............ & 1.3 \\
\hline pallokenttänä ........................ & 0.5 \\
\hline 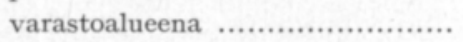 & 0.2 \\
\hline muu käyttő ............... & 1.0 \\
\hline käyttö johonkin ............ & 49.8 \\
\hline
\end{tabular}

\section{Käyttöön vaikuttavat tekijät}

Kyselyssä tärkeimmiksi osoittautuneet tilojen vakituista asuttamista, palstojen metsitystä, palstojen käyttämistä laiduntamiseen, sekä palstojen käyttöä johonkin muuhun tarkoitukseen selittävät tekijät on esitetty taulukoissa 1-4. Käyttöön vaikuttavat yhteiskunnalliset, sosiaaliset, yms. tekijät ovat tämän tutkimuksen ulkopuolella.

\section{Vakituinen asuminen tilalla}

Tilojen autioitumista selittävistä parametreista useimmat ilmentävät tilan yksinäisyyttä ja eristyneisyyttä, mitkä selvästi alentavat halukkuutta asua kyseisillä tiloilla. Mikäli peltoja on hoidettu (esim. ovat salaojitetut tai niille on kylvetty nurmi paketointiaikana) asutaan tilalla vakituisesti huomattavasti useammin. 
Taulukko 1. Tilojen vakituista asuttamista selittävät tekijät.

Table 1. Factors explaining permanent residence of farms.

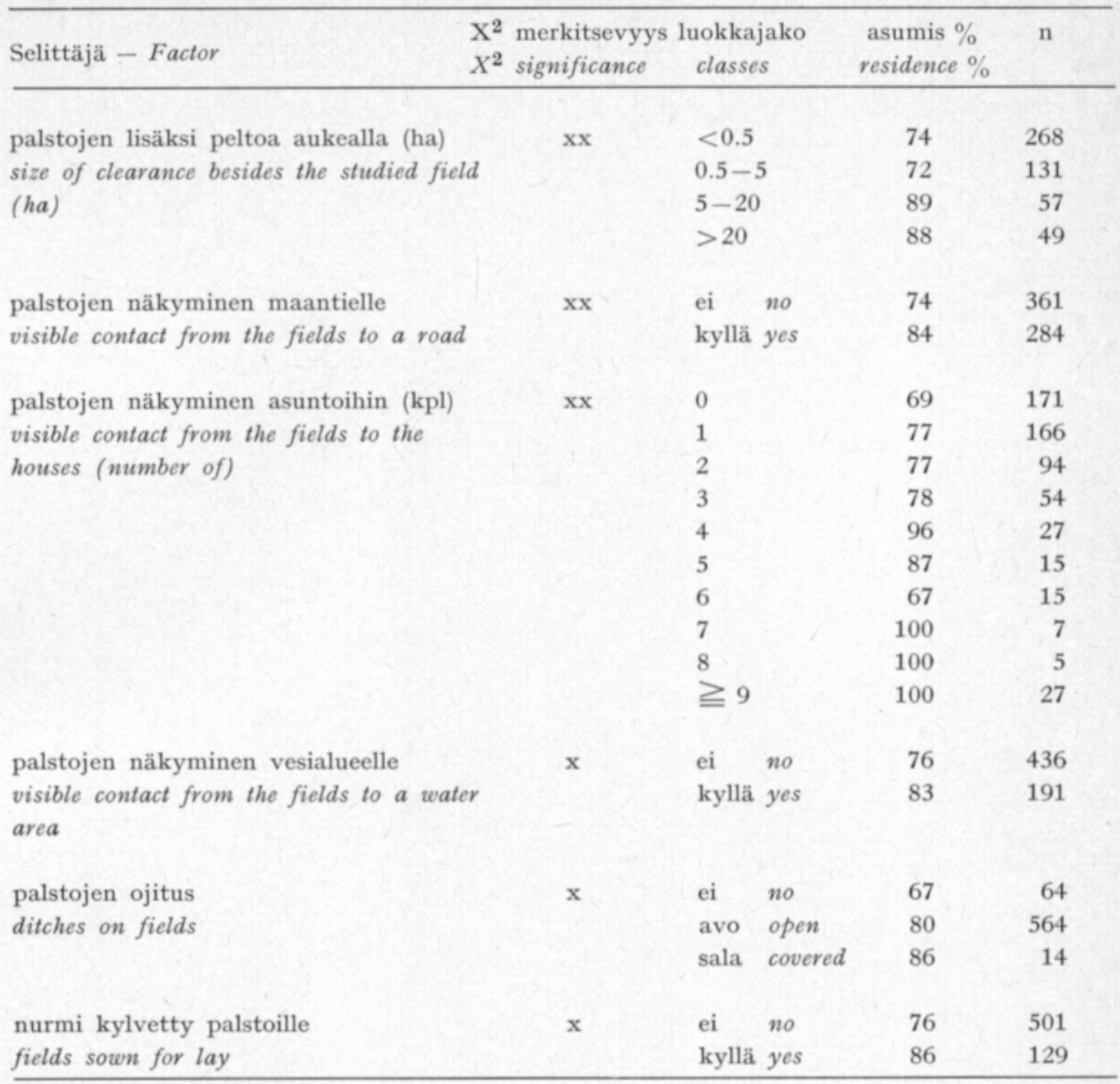

$\mathrm{xxx}=\mathrm{p}<0.001, \mathrm{xx}=\mathrm{p}<0.01, \mathrm{x}=\mathrm{p}<0.05$,

$\mathrm{n}=$ palstojen lukumäärä kussakin luokassa.

$n=$ number of fields in each class.

\section{Metsitys}

Pakettipeltopalstojen metsitykseen vaikuttavista seikoista tärkeimmiksi osoittautuivat palstan kokoa ja sijaintia koskevat piirteet. Pienikokoiset, etäällä liikenneväylistä sijaitsevat palstat olivat altteimmat metsitykselle. Muihin selittäjiin liittyvänä ja metsitykseen voimakkaasti vaikuttavana tekijänä tuli esille myös palstan aiempi käyttö. Selvimmin erottuivat laitumena olleet palstat, joista oli metsitetty yli puolet, ja perunalla olleet palstat, joista oli metsitetty vain vajaa kymmenesosa. Palstan ominaisuuksista oli vaikutusta myös sen etäisyydellä tilan päärakennuksesta sekä sillä, kuinka moneen asumukseen palsta oli nähtävissä. Lähellä päärakennusta sijaitsevia peltoja sekä palstoja, jotka näkyivät moneen asumukseen, oli metsitetty selvästi vähemmän kuin etäämmällä olevia, yksinäisiä palstoja. 
Taulukko 2. Palstojen metsitystä selittävät tekijät. Symbolit kuten taulukossa 1.

Table 2. Factors explaining afforestation of fields. Symbols as in Table 1.

\begin{tabular}{|c|c|c|c|c|c|}
\hline $\begin{array}{l}\text { Selittäjä } \\
\text { Factor } \\
\end{array}$ & $\begin{array}{l}\text { kitsevyys } \\
\text { nificance }\end{array}$ & $\begin{array}{r}\text { luokk } \\
\text { clas }\end{array}$ & $\begin{array}{l}\text { kajako } \\
\text { isses }\end{array}$ & $\begin{array}{l}\text { metsitys \% } \\
\text { afforestation \% }\end{array}$ & $\mathrm{n}$ \\
\hline $\begin{array}{l}\text { palstan pinta-ala (ha) } \\
\text { area of the field (ha) }\end{array}$ & $\mathbf{x x x}$ & $\begin{array}{l}<0.5 \\
0.5-1 \\
1-2 \\
2-5 \\
5-10 \\
>10\end{array}$ & & $\begin{array}{r}27 \\
38 \\
22 \\
17 \\
15 \\
8\end{array}$ & $\begin{array}{r}44 \\
103 \\
178 \\
241 \\
61 \\
13\end{array}$ \\
\hline $\begin{array}{l}\text { palstan etäisyys } \\
\text { liikenneväylästä (m) } \\
\text { distance of the field from a } \\
\text { traffic route }(\mathrm{m})\end{array}$ & $\mathbf{x x x}$ & $\begin{array}{l}0-5 \\
6-50 \\
51-500 \\
501-5000 \\
<5000\end{array}$ & & $\begin{array}{l}14 \\
19 \\
29 \\
20 \\
70\end{array}$ & $\begin{array}{r}136 \\
75 \\
206 \\
148 \\
10\end{array}$ \\
\hline $\begin{array}{l}\text { palstan näkyminen maantielle } \\
\text { visible contact from the field } \\
\text { to a road }\end{array}$ & $\mathrm{xxx}$ & $\begin{array}{l}\text { ei } \\
\text { kyllä }\end{array}$ & $\begin{array}{l}\text { no } \\
\text { yes }\end{array}$ & $\begin{array}{l}28 \\
15\end{array}$ & $\begin{array}{l}360 \\
285\end{array}$ \\
\hline $\begin{array}{l}\text { palstan aikaisempi käyttö } \\
\text { former use of the field }\end{array}$ & $\mathrm{xxx}$ & $\begin{array}{l}\text { laidun } \\
\text { syysvilja } \\
\text { nurmi } \\
\text { kevätvilja } \\
\text { peruna }\end{array}$ & $\begin{array}{l}\text { pasture } \\
\text { autumn cereal } \\
\text { ley } \\
\text { spring cereal } \\
\text { potato }\end{array}$ & $\begin{array}{r}56 \\
50 \\
26 \\
18 \\
9\end{array}$ & $\begin{array}{r}34 \\
8 \\
257 \\
157 \\
11\end{array}$ \\
\hline $\begin{array}{l}\text { palstan etäisyys } \\
\text { päärakennuksesta (m) } \\
\text { distance from the field to the } \\
\text { main building }(\mathrm{m})\end{array}$ & $x$ & $\begin{array}{l}0-5 \\
6-50 \\
51-500 \\
501-5000 \\
>5000\end{array}$ & & $\begin{array}{l}14 \\
18 \\
28 \\
26 \\
25\end{array}$ & $\begin{array}{r}84 \\
204 \\
208 \\
103 \\
4\end{array}$ \\
\hline $\begin{array}{l}\text { palstan näkyminen } \\
\text { asuntoihin (kpl) } \\
\text { visible contact from the } \\
\text { field to the houses } \\
\text { (number of) }\end{array}$ & $x$ & $\begin{array}{l}0 \\
1 \\
2 \\
3-5 \\
\geqq 6\end{array}$ & & $\begin{array}{r}32 \\
23 \\
21 \\
17 \\
9\end{array}$ & $\begin{array}{r}171 \\
166 \\
94 \\
96 \\
54\end{array}$ \\
\hline $\begin{array}{l}\text { tilan paketoimisvuosi } \\
\text { year of reservation }\end{array}$ & $\mathbf{x x x}$ & $\begin{array}{l}1969 \\
1970 \\
1971 \\
1972 \\
1973 \\
1974\end{array}$ & & $\begin{array}{r}25 \\
20 \\
34 \\
24 \\
9 \\
0\end{array}$ & $\begin{array}{r}202 \\
90 \\
79 \\
55 \\
122 \\
18\end{array}$ \\
\hline $\begin{array}{l}\text { tilan paketoitu peltoala (ha) } \\
\text { reserved field area in the } \\
\text { farm (ha) }\end{array}$ & $\mathbf{x x}$ & $\begin{array}{l}<3 \\
3-5 \\
5-10 \\
>10\end{array}$ & & $\begin{array}{l}26 \\
16 \\
29 \\
15\end{array}$ & $\begin{array}{r}101 \\
201 \\
249 \\
98\end{array}$ \\
\hline $\begin{array}{l}\text { tilan peltopalstojen lukumäärä } \\
\text { number of fields of the farm }\end{array}$ & $\mathbf{x x x}$ & $\begin{array}{l}1 \\
2 \\
3 \\
4 \\
5 \\
6 \\
7 \\
8\end{array}$ & & $\begin{array}{l}14 \\
14 \\
19 \\
36 \\
40 \\
38 \\
50 \\
12\end{array}$ & $\begin{array}{r}95 \\
162 \\
187 \\
128 \\
20 \\
12 \\
28 \\
16\end{array}$ \\
\hline $\begin{array}{l}\text { tilan kokonaispinta-ala (ha) } \\
\text { total area of the farm (ha) }\end{array}$ & $\mathrm{xx}$ & $\begin{array}{l}<5 \\
5-10 \\
10-20 \\
20-50 \\
50-100 \\
>100\end{array}$ & & $\begin{array}{l}10 \\
10 \\
22 \\
18 \\
34 \\
26\end{array}$ & $\begin{array}{r}10 \\
20 \\
112 \\
309 \\
135 \\
39\end{array}$ \\
\hline $\begin{array}{l}\text { tilan omistustyyppi } \\
\text { ownership of the farm }\end{array}$ & $x$ & $\begin{array}{l}\text { yksityinen, } \\
\text { yhteisö }\end{array}$ & $\begin{array}{l}\text { private } \\
\text { public }\end{array}$ & $\begin{array}{r}23 \\
0\end{array}$ & $\begin{array}{r}636 \\
13\end{array}$ \\
\hline
\end{tabular}


Eräät koko tilaa koskevat tiedot selittivät merkittävässä määrin metsitysalttiutta. Tilan paketoimisvuotena erottuu vuosi 1971 selvästi muista innokkaan metsityksen vuotena. Tämä on selvästi seurausta Asutushallituksen talvella $1970 / 71$ antamista kehoituksista tehostaa syrjäisten palstojen metsittämistä (ANoN. 1970 ja 1971 a). Peltopalstojen suuri lukumäärä tilalla lisää myös metsitysalttiutta - tällöin pellot ovat ilmeisen pirstaleina, ja ne on järkevä metsittää. Tilan kokonaispinta-alan ollessa 50-100 ha, mutta paketoidun peltoalan ollessa kuitenkin alle 10 ha, on innokkuus metsittämiseen myös suuri. Vielä asiaan vaikuttavana koko tilaa koskevana seikkana on tilan omistustyyppi: yhteisöjen pakettipeltoja ei Keski-Suomessa oltu vuonna 1974 metsitetty lainkaan.

Jotkut tutkituista parametreistä selittivät myös istutettujen puulajien jakautumista erityyppisille palstoille. Paketoimisvuosi vaikutti siten, että kuusen ja koivun osuus laski pellonvarausjärjestelmän vanhetessa, kun taas männyn osuus pysyi kutakuinkin ennallaan. Metsitysviiveen vaikutus puolestaan korjasi tilannetta koivun osalta, sillä sitä on yleensä istutettu vasta useita vuosia paketoinnin jälkeen. Mäntyä ja kuusta on istutettu lähinnä vain paketointivuotena ja mutamana sitä seuranneena lähivuotena. Puulajijakaumaan vaikutti vielä palstan aiempi käyttö hyvin voimakkaasti ainakin laitumena olleiden palstojen osalta, joista kaikista peräti $35 \%$ oli istutettu koivulle (63\% laitumen jälkeen metsitetyistä palstoista).

\section{Laiduntaminen}

Peltopalstojen laiduntamiseen vaikuttaneet tekijät on esitelty taulukossa 3 .

Taulukko 3. Palstojen laiduntamista selittävät tekijät. Symbolit kuten taulukossa 1. Table 3. Factors explaining pasturage on fields. Symbols as in Tab. 1.

\begin{tabular}{|c|c|c|c|c|}
\hline Selittäjä - Factor & $\begin{array}{l}\mathrm{X}^{2} \text { merkitsevyys } \\
X^{2} \text { significance }\end{array}$ & $\begin{array}{c}\text { luokkajako } \\
\text { classes }\end{array}$ & $\begin{array}{l}\text { laidunnus } \% \\
\text { pastụrage } \%\end{array}$ & $\mathrm{n}$ \\
\hline \multirow{2}{*}{$\begin{array}{l}\text { nurmi kylvetty palstalle } \ldots . . . \ldots \ldots \ldots \ldots \ldots . . . . . . \\
\text { fields sown for lay }\end{array}$} & \multirow[t]{2}{*}{$\mathbf{x x x}$} & ei no & 4 & 500 \\
\hline & & kyllä yes & 15 & 126 \\
\hline \multirow{6}{*}{ 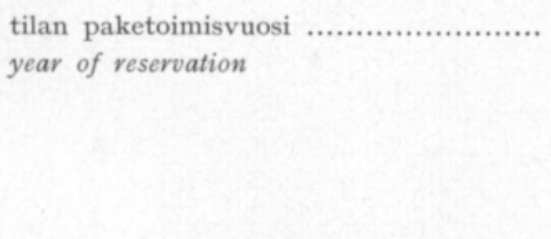 } & \multirow[t]{6}{*}{$\operatorname{xxx}$} & 1969 & 2 & 200 \\
\hline & & 1970 & 2 & 89 \\
\hline & & 1971 & 17 & 79 \\
\hline & & 1972 & 9 & 55 \\
\hline & & 1973 & 9 & 121 \\
\hline & & 1974 & 22 & 18 \\
\hline \multirow{6}{*}{$\begin{array}{l}\text { tilan kokonaispinta-ala (ha) } \\
\text { total area of the farm (ha) }\end{array}$} & \multirow[t]{6}{*}{$\mathbf{x x}$} & $<5$ & 20 & 10 \\
\hline & & $5-10$ & 10 & 20 \\
\hline & & $10-20$ & 6 & 108 \\
\hline & & $20-50$ & 8 & 308 \\
\hline & & $50-100$ & 2 & 135 \\
\hline & & $>100$ & 6 & 39 \\
\hline \multirow{4}{*}{ 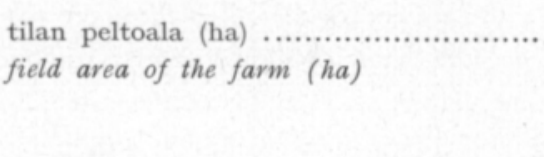 } & \multirow[t]{4}{*}{$\mathbf{x x}$} & $<3$ & 1 & 91 \\
\hline & & $3-5$ & 5 & 200 \\
\hline & & $5-10$ & 9 & 245 \\
\hline & & $>10$ & 7 & 99 \\
\hline
\end{tabular}


Sellaisia palstoja, joille on kylvetty nurmi paketoimisen jälkeen, laidunnettiin selvästi useammin kuin muita. Samaten nuorilla, vähän aikaa paketissa olleilla pelloilla laiduntaminen oli yleisempää kuin vanhoilla pakettipelloilla. Tämä johtui pääasiassa hevosen laiduntamisen vähenemisestä, mikä oli selvää pakettipellon iän kasvaessa. Lampaiden laiduntamisessa vastaaváa eroa ei todettu. Tilan kokonaispinta-alalla sen sijaan oli suuri merkitys lampaiden laiduntamiselle: pienikokoisilla tiloilla tämä oli huomattavasti yleisempää kuin suuremmilla, yli 10 ha:n tiloilla. Laiduntaminen yleensä oli kuitenkin harvinaista tiloilla, joiden peltoala oli alle 3 ha.

\section{Muи käyttö}

Palstojen muu käyttö oli pääasiassa perunan ja juurikasvien kotitarveviljelyä, joten selvästi tärkein selittävä seikka oli palstan sijainti lähellä päärakennusta. Muusta käytöstä ainoastaan riistapeltona pitäminen jakautui eri tavalla: runsainta se oli palstoilla, jotka sijaitsivat $0.5-5 \mathrm{~km}: n$ päässä päärakennuksesta. Toinen muuta käyttöä selittävä selvä tekijä oli tilan omistustyyppi - yhteisöjen pelloilla ei juurikaan ollut kyseisentyyppistä käyttöä.

Taulukko 4. Palstojen kãyttöã muuhun kuin metsittämiseen tai laiduntamiseen selittävät tekijät. Symbolit kuten taulukossa 1.

Table 4. Factors explaining the use of fields for other purposes than afforestation and pasturage. Symbols as in Table 1.

\begin{tabular}{lccrr}
\hline Selittäjä - Factor & $\begin{array}{c}X^{2} \text { merkitsevyys } \\
X^{2} \text { significance }\end{array}$ & $\begin{array}{c}\text { luokkajako } \\
\text { classes }\end{array}$ & $\begin{array}{c}\text { käyttö \% } \\
\text { usage } \%\end{array}$ & $\mathrm{n}$ \\
\hline palstan etäisyys päärakennuksesta (m) & $\mathbf{x x x}$ & $0-5$ & 45 & 82 \\
distance from the field to the main & $6-50$ & 43 & 201 \\
building $(m)$ & $51-500$ & 8 & 202 \\
& $501-5000$ & 6 & 101 \\
& $>5000$ & 0 & 4 \\
tilan omistustyyppi & yksityinen private & 25 & 623 \\
ownership of the farm & yhteisö public & 8 & 12 \\
\hline
\end{tabular}

\section{Pakettipeltojen hoito}

Pellonvaraussopimuksessa annetaan hyvin vähän ohjeita hoitomenetelmistä: "Ellei korvauksen alainen pelto ole laadultaan sellaista, että se välittömästi ruohottuu, viljelijän on huolehdittava siitä, ettei pelto siinä määrin rikkaruohotu, että siitä olisi haittaa ympäristön viljelyksille. Tämän estämiseksi viljelijä voi ilman suojaviljaa kylvää pellon nurmelle. Viljelijän on estettävä korvauksen alaisen pellon haitallinen vesottuminen.» RAATIKAINEN ym. (1971) on seikkaperäisesti esitellyt eri vaihtoehdot pakettipeltojen rikkakasvien kurissapitämiseksi, pitäen tuottamattomilla pelloilla ehkä parhaimpina menetelminä rikkakasvihävitteillä käsittelyä tai kasvilajiseoksella kylvämistä. Tuottavien pakettipeltojen käyttö- ja hoitomenetelmistä on tuotu esiin laiduntaminen, mesikasvinurmena ja riistapeltona pito sekä metsitys. Julki- 
suudessa on muuallakin suositeltu nurmen perustamista sopivana hoitomenetelmänä (TAKALA 1973). Maatalousviranomaiset ovat korostaneet varsinkin toisten viljelysten läheisyydessä ja teiden varsilla olevien peltojen hoitoa esim. nurmettamalla tai niittämällä (ANoN. 1971 b ja 1973). Nurmena pitoa vastaan puhuvat kuitenkin niillä tavattavat suuremmat tuhoeläintiheydet luonnonniittyihin tai luonnontilaisiin pakettipeltoihin verrattuna (HoKkANEN ja RAATIKAINEN 1978). Kyntäminen puolestaan pahentaa rikkakasvitilannetta niin, ettei sitä enää varauksettomasti suositellakaan hoitomenetelmäksi (TörmäL 1977). Niittäminen on todettu sopivaksi hoitomenetelmäksi sekä rikkakasveja että tuhohyönteisiä ajatellen (TörmäLÄ 1977). Mikäli ongelmana ovat myyrät, lienee kyntäminen kuitenkin ainoa tehokas hoitokeino.

Keski-Suomen pakettipeltoja hoidettiin kesällä 1974 seuraavasti:

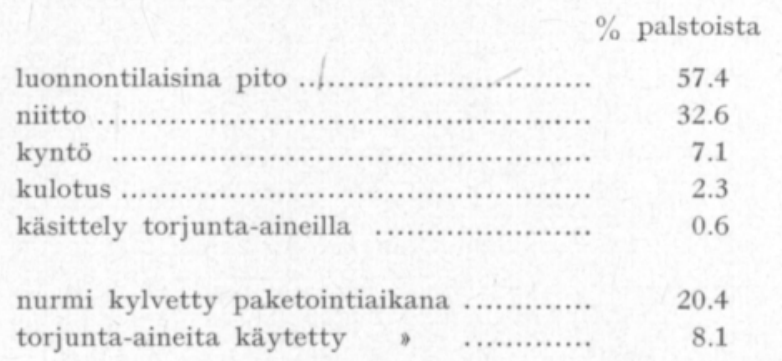

Torjunta-aineita oli käytetty pääasiassa metsitetyillä palstoilla lähinnä heinittymistä vastaan, kaikkiaan $23.3 \%$ :lla niistä. Vesakontorjunta-aineita oli käytetty $5.5 \%$ lla metsitetyistä palstoista. Metsittämättömillä palstoilla torjunta-aineita oli käytetty vesakontorjuntaan $1.6 \%$ :lla ja heinäntorjuntaan $0.6 \%$ :lla palstoista. Joillakin metsitetyillä palstoilla heinittymistä oli torjuttu myös niittämällä taimien ympärykset tai polkemalla heinät nurin.

Palstoja niitettäessä ei läheskään aina niitetty koko aluetta, vaan yli kolmasosassa tapauksista $(36.2 \%)$ pelkästään ojanpenkat ja joskus $(13.0 \%)$ pelkästään palstan keskusta. $3.9 \%$ niitoista kohdistui taimien ympäryksiin metsitetyillä palstoilla.

Niitto- ja kyntöajankohdat vaihtelivat suuresti, painottuen kuitenkin keski(niitto) tai alkukesään (kyntö):

\begin{tabular}{|c|c|c|c|}
\hline niitto/kynt & öajankohta & $\begin{array}{l}\% \text { niitetyistä } \\
\text { palstoista }\end{array}$ & $\begin{array}{c}\% \text { kynnetyistä } \\
\text { palstoista }\end{array}$ \\
\hline kesãkuun & alku...$\ldots \ldots \ldots \ldots \ldots \ldots$ & 5.1 & 45.5 \\
\hline , & puoliväli ................ & 10.3 & 6.8 \\
\hline , & loppu ..................... & 6.3 & - \\
\hline heinäkuun & 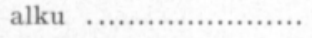 & 14.9 & - \\
\hline , & puoliväli ................ & 25.7 & 36.4 \\
\hline - & 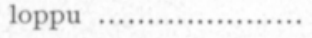 & 14.9 & - \\
\hline elokuun & 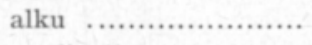 & 10.3 & - \\
\hline , & puoliväli $\quad$................ & 8.0 & 2.3 \\
\hline , & loppu $\ldots \ldots \ldots \ldots \ldots \ldots . . . . . . . .$. & 4.6 & 9.1 \\
\hline n $\ldots \ldots$ & & 175 & 44 \\
\hline
\end{tabular}


Hoitotoimenpiteiden ajoittumisella on suuri merkitys ympäristön kannalta, sillä esim. pahimpien rikkakasvien siementämisen jälkeen suoritetulla niitolla ei ole juuri merkitystä muuten kuin palstan vesottumisen kannalta. Tässä suhteessa palstat niitettiin yleensä liian myöhään, kyntäminen taas ajoittui valtaosin oikea-aikaisesti.

Vastaajilta kysyttiin myös heidän mielipidettään pakettipeltojen mielekkäimmästä hoitotavasta. Vastausten frekvenssijakauma esitetään seuraavassa asetelmassa; 25.9 \% mainitsi kaksi tapaa esittämättä niiden keskinäistä paremmuutta - nämä molemmat otettiin huomioon frekvenssejä laskettaessa.

\begin{tabular}{|c|c|}
\hline mielekkäin hoitotapa & $\%$ vastaajista \\
\hline metsittäminen .......... & 30.7 \\
\hline niittäminen & 23.9 \\
\hline luonnontilaisena pito ................ & 13.9 \\
\hline kyntäminen & 7.4 \\
\hline 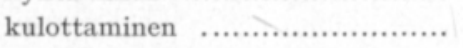 & 4.0 \\
\hline 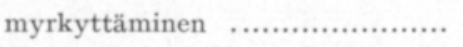 & 3.4 \\
\hline 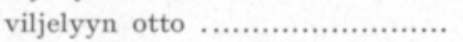 & 2.9 \\
\hline 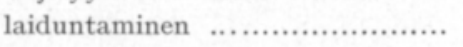 & 2.2 \\
\hline 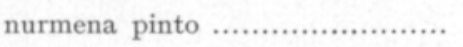 & 1.3 \\
\hline mielipidettä & 10.3 \\
\hline
\end{tabular}

\section{Hoitoon vaikuttavat tekijät}

Kyselyssä esille tulleille hoitoon vaikuttaville lukuisille tekijöille on yhteistä se, että ne lähes poikkeuksetta selittävät eroja ainoastaan sen välillä hoidetaanko peltoja yleensä vai eikö hoideta. Eri hoitotapojen välisiä eroja tutkituista parametreista osoitti vain peltojen paketissaoloikä, muissa tapauksissa eri hoitomenetelmät jakautuivat suurin piirtein samassa suhteessa. Paketissaoloiänkään vaikutus ei osoita muutoksia muun hoitomenetelmän kuin kulotuksen osalta, missä tapahtuu hyvin selvä osuuden lisääntyminen paketissaoloiän vähetessä. Esim. vuosina 1969 ja 1970 paketoiduista pelloista kulotettiin vain $1 \%(\mathrm{n}=300)$, mutta vuosina 1973 ja 1974 paketoiduista jo $6 \%(\mathrm{n}=143)$.

Hoitoon vaikuttavat tekijät on esitetty taulukossa 5. Hoidetuimpia ovat olleet pellot, joita on käytetty johonkin (poisluettuna metsitys, jolla on päinvastainen vaikutus); samoin suurikokoiset, näkyvillä paikoilla sijainneet palstat. Yhteisöjen peltoja hoidettiin paljon aktiivisemmin kuin pakettipeltoja keskimäärin. Yksityisillä hoitohalukkuutta lisäsi tilalla asuminen, varsinkin mikäli tila oli osan vuotta myös ulkopuolisten käytössä (esim. kesäasuntona). Pelkästään ulkopuolisten käytössä olleiden tilojen peltoja hoidettiin kaikkein vähiten.

Hoitotoimenpiteet ovat pääosin kohdistuneet juuri sellaisiin peltoihin, joihin niiden määräysten ja ohjeiden mukaan ensisijaisesti tulisikin kohdistua: muiden viljelysten yhteydessä ja teiden varsilla oleviin peltoihin. Syyt siihen, että läheskään kaikkia näitäkään ei kuitenkaan hoideta toivomusten mukaisesti, lienevät pääasiassa käytännöllis - taloudellis - sosiaalisia (ja täten tämän tutkimuksen ulkopuolella): sopivaa välineistöä ei enää ole, vieraalla työtä ei kannata teettää, omistaja on muuttanut pois tai ei kykene työtä tekemään sairauden tms. syyn takia, jne. 
Taulukko 5. Pakettipeltojen hoitoa selittävät tekijät. Symbolit kuten taulukossa 1.

Table 5. Factors explaining management of fields. Symbols as in Table 1.

\begin{tabular}{|c|c|c|c|c|c|}
\hline $\begin{array}{l}\text { Selittäjä } \\
\text { Factor }\end{array}$ & $\begin{array}{c}\mathrm{X}^{2} \text { merkitsevyys } \\
X^{2} \text { significance }\end{array}$ & $\begin{array}{l}\text { luokkaja } \\
\text { classes }\end{array}$ & ako & $\begin{array}{l}\text { hoito } \% \\
\text { management } \%\end{array}$ & $\mathrm{n}$ \\
\hline $\begin{array}{l}\text { tilan peltoala (ha) } \\
\text { field area of the farm (ha) }\end{array}$ & $\mathrm{xxx}$ & $\begin{array}{l}<3 \\
3-5 \\
5-10 \\
>10\end{array}$ & & $\begin{array}{l}43 \\
31 \\
48 \\
52\end{array}$ & $\begin{array}{r}204 \\
251 \\
99 \\
101\end{array}$ \\
\hline $\begin{array}{l}\text { tilan omistustyyppi } \\
\text { owership of the farm }\end{array}$ & $\mathrm{xxx}$ & $\begin{array}{l}\text { yksityinen } \\
\text { yhteisö }\end{array}$ & $\begin{array}{l}\text { private } \\
\text { public }\end{array}$ & $\begin{array}{l}41 \\
74\end{array}$ & $\begin{array}{r}626 \\
34\end{array}$ \\
\hline $\begin{array}{l}\text { tilalla asuja } \\
\text { inmate of the form }\end{array}$ & $\mathbf{x x}$ & $\begin{array}{l}\text { omistaja } \\
\text { ulkopuolinen } \\
\text { sekä-että }\end{array}$ & $\begin{array}{l}\text { owner } \\
\text { outsider } \\
\text { both }\end{array}$ & $\begin{array}{r}41 \\
9 \\
59\end{array}$ & $\begin{array}{r}540 \\
13 \\
29\end{array}$ \\
\hline $\begin{array}{l}\text { tilalla asuminen } \\
\text { residence on the farm }\end{array}$ & $x$ & $\begin{array}{l}\text { ei } \\
\text { kyllä }\end{array}$ & $\begin{array}{l}\text { no } \\
\text { yes }\end{array}$ & $\begin{array}{l}33 \\
44\end{array}$ & $\begin{array}{l}138 \\
500\end{array}$ \\
\hline $\begin{array}{l}\text { palstojen metsitys } \\
\text { afforestation of the fields }\end{array}$ & $x x$ & $\begin{array}{l}\text { ei } \\
\text { kyllä }\end{array}$ & $\begin{array}{l}\text { no } \\
\text { yes }\end{array}$ & $\begin{array}{l}45 \\
31\end{array}$ & $\begin{array}{l}499 \\
140\end{array}$ \\
\hline $\begin{array}{l}\text { palstojen lainduntaminen } \\
\text { pasturage of the fields }\end{array}$ & $\mathrm{xxx}$ & $\begin{array}{l}\text { ei } \\
\text { kyllä }\end{array}$ & $\begin{array}{l}\text { no } \\
\text { yes }\end{array}$ & $\begin{array}{l}39 \\
71\end{array}$ & $\begin{array}{r}595 \\
38\end{array}$ \\
\hline $\begin{array}{l}\text { palstojen muu käyttö } \\
\text { other use of the fields }\end{array}$ & $\mathrm{xxx}$ & $\begin{array}{l}\text { ei } \\
\text { kyllä }\end{array}$ & $\begin{array}{l}\text { no } \\
\text { yes }\end{array}$ & $\begin{array}{l}38 \\
55\end{array}$ & $\begin{array}{l}475 \\
150\end{array}$ \\
\hline $\begin{array}{l}\text { nurmi kylvetty palstalle } \\
\text { field sown for ley }\end{array}$ & $\mathrm{xxx}$ & $\begin{array}{l}\text { ei } \\
\text { kyllä }\end{array}$ & $\begin{array}{l}\text { no } \\
\text { yes }\end{array}$ & $\begin{array}{l}38 \\
57\end{array}$ & $\begin{array}{l}493 \\
129\end{array}$ \\
\hline $\begin{array}{l}\text { palstan näkyminen } \\
\text { asuntoihin (kpl) } \\
\text { visible contact from the field } \\
\text { to the houses (number of) }\end{array}$ & $\mathrm{xxx}$ & $\begin{array}{l}0 \\
1 \\
2 \\
3 \\
4 \\
5 \\
\geqq 6\end{array}$ & & $\begin{array}{l}32 \\
41 \\
43 \\
43 \\
46 \\
58 \\
68\end{array}$ & $\begin{array}{r}171 \\
164 \\
97 \\
54 \\
28 \\
19 \\
63\end{array}$ \\
\hline $\begin{array}{l}\text { palstan etäisyys } \\
\text { päärakennuksesta }(\mathrm{m}) \\
\text { distance from the field to the } \\
\text { main building }(\mathrm{m})\end{array}$ & $\mathbf{x x x}$ & $\begin{array}{l}0-5 \\
6-50 \\
51-500 \\
501-5000 \\
>5000\end{array}$ & & $\begin{array}{r}57 \\
47 \\
37 \\
29 \\
0\end{array}$ & $\begin{array}{r}83 \\
203 \\
204 \\
101 \\
4\end{array}$ \\
\hline $\begin{array}{l}\text { palstan näkyminen } \\
\text { maantielle } \\
\text { visible contact from the field } \\
\text { to a road }\end{array}$ & $\mathrm{xxx}$ & $\begin{array}{l}\text { ei } \\
\text { kyllä }\end{array}$ & $\begin{array}{l}\text { no } \\
\text { yes }\end{array}$ & $\begin{array}{l}33 \\
53\end{array}$ & $\begin{array}{l}356 \\
301\end{array}$ \\
\hline $\begin{array}{l}\text { palstan etäisyys } \\
\text { liikenneväylästä (m) } \\
\text { distance from the field to } \\
\text { a traffic route }(\mathrm{m})\end{array}$ & $x x$ & $\begin{array}{l}0-5 \\
6-50 \\
51-500 \\
501-5000 \\
<5000\end{array}$ & & $\begin{array}{l}51 \\
47 \\
41 \\
33 \\
10\end{array}$ & $\begin{array}{r}152 \\
74 \\
205 \\
147 \\
10\end{array}$ \\
\hline $\begin{array}{l}\text { palstan pinta-ala (ha) } \\
\text { area of the field (ha) }\end{array}$ & $\mathrm{xx}$ & $\begin{array}{l}<0.5 \\
0.5-1 \\
1-2 \\
2-5 \\
5-10 \\
>10\end{array}$ & & $\begin{array}{l}30 \\
32 \\
40 \\
49 \\
58 \\
38\end{array}$ & $\begin{array}{r}44 \\
101 \\
179 \\
253 \\
62 \\
13\end{array}$ \\
\hline $\begin{array}{l}\text { palstan lisäksi aukealla } \\
\text { peltoa (ha) } \\
\text { size of clearance besides the } \\
\text { studied field (ha) }\end{array}$ & $x$ & $\begin{array}{l}<0.5 \\
0.5-5 \\
5-20 \\
>20\end{array}$ & & $\begin{array}{l}40 \\
47 \\
52 \\
58\end{array}$ & $\begin{array}{r}263 \\
137 \\
64 \\
52\end{array}$ \\
\hline
\end{tabular}




\section{Yhteenveto}

Keskisuomalainen pellonvaraustila ei ominaisuuksiltaan paljoa poikkea alueen muista maatiloista. Koko valtakuntaa ajatellen erot maan eri osien välillä nimenomaan peltojen koossa ja sijainnissa ovat kuitenkin niin suuret, että kovin laajoihin yleistyksiin ei tämänkään tutkimuksen pohjalta voida mennä.

Tutkimusalueella pakettipeltopalstat ovat enimmäkseen suhteellisen pienialaisia, avo-ojin varustettuja ja nurmen jälkeen paketoituja. Palstat sijaitsevat yleensä erillään muista pelloista, ja ne näkyvät useimmiten korkeintaan yhteen asumukseen. Yleiselle maantielle niistä näkyy hieman alle puolet ja vesialueelle vajaa kolmannes.

Valtaosalla tiloista asutaan vakituisesti, ja ainakin osan vuotta asuttuna niistä on $91.7 \%$. Pellonvarauslain suomia peltojen käyttömahdollisuuksia on alueella käytetty hyväksi vähän, vain palstojen metsittäminen ja kotitarveperunan ja -juureksien viljely olivat jokeseenkin yleisiä käyttötapoja. Noin puolella palstoista oli ollut jonkinlaista käyttöä kesällä 1974 .

Metsitys oli useimmiten kohdistunut pienimpiin ja syrjäisimpiin palstoihin, mikä onkin hyvin pellonvarauslain hengen mukaista. Muu käyttö kohdistui lähinnä tiloille, joilla oli muutakin toimintaa, ja palstoille, jotka sijaitsivat edullisesti. Niinpä laiduntaminen kohdistui usein palstoihin, joille oli kylvetty nurmi ja joita muutenkin hoidettiin, ja kotitarveviljely puolestaan asuttujen tilojen lähellä päärakennusta sijainneisiin palstoihin.

Suurinta osaa pakettipelloista ei hoidettu mitenkään vuonna 1974. Yleisin hoitomenetelmä oli niitto - lähes kolmannes palstoista niitettiin. Pieni osa niistä kynnettiin, ja joitakin palstoja kulotettiin tai käsiteltiin torjunta-aineilla. Noin viidesosalle palstoista oli kylvetty nurmi paketointiaikana. Hoitotoimenpiteet, varsinkin niitto, ajoittuivat kuitenkin yleensä huonosti rikkakasvien leviämistä ajatellen. Hoito keskittyi lähinnä suurikokoisille, näkyvillä paikoilla sijainneille palstoille, mikä myös hyvin vastaa toimenpiteistä annettuja (minimi) ohjeita.

KIITOKSET. Haluan kiittää kaikkia kyselyyn myönteisesti suhtautuneita vastaajia, jotka tekivät tutkimuksen suorittamisen mahdolliseksi. Tyồn ohjauksesta ja käsikirjoituksen tarkastamisesta esitän parhaat kiitokseni prof. Mikko Raatikaiselle. Työn rahoitti valtion luonnontieteellinen toimikunta.

\section{KIRJALLISUUSLUETTELO}

Anon. 1970: Asutushallitus, Pellonvaraustoimisto, kiertokirje 22/3700-70.

- 1971 a: Asutushallitus, Pellonvaraustoimisto, kiertokirje 7/3700-71.

- 1971 b: Maatilahallitus, Maanhoitotoimisto, kiertokirje n:o 11/3700-71.

- 1972: Laukaan maatalouden rakennerationalisointitutkimus vuosina 1970-71. KeskiSuomen Maatalouskeskus.

- 1973: Maatilahallitus, Maanhoitotoimisto, kiertokirje 12/3700-73.

- 1974: Pohjoisen Keski-Suomen maatilatalouden kehittämissuunnitelma. KeskiSuomen Maatalouskeskus.

- 1975: Keski-Suomen läänin maatalouden perusselvitys. Keski-Suomen Lääninhall. Julk. A, 13/1975.

- 1976: Keski-Suomen maatilatalouden kehittămisohjelma. Keski-Suomen Lääninhall. Julk. A, 16/1976. 
Hokkanen, H. \& RaAtikainen, M. 1977: Yield, vegetation and succession in reserved fields in Central Finland. J. Scient. Agric. Soc. Finl. 49: 221-238.

- \& RAatikainen, M. 1978: Faunal communities of the field stratum and their succession in reserved fields. J. Scient. Agric. Soc. Finl. 49: 390-405.

JAATiNen, S. \& KäRKKÄINen, U. 1971: Vuoden 1969 pellonvaraustoiminta. Hels. Yliop. Maantiet. Lait. Julk. B, 7.

- \& NYGẢRD, M. 1973: Pellonvaraustoiminta Suomessa paikallisella tasolla. Terra 85: $149-162$.

Juntunen, E. 1978: Pellonvaraustoiminta ja sen vaikutukset Pohjois-Pohjanmaalla. Oulun Yliop. Pohjois-Suomen Tutk.lait. C, 13.

RaAtikainen, M., RaAtikainen, T. \& Tinnilä, A. 1971: Rikkakasvit ja niiden torjunta. Kasvinsuoj.seur. Julk. 46: 1-108.

TAKALA, M. 1973: Viljelyksestä poistettujen peltojen hoito. Koetoim.ja Käyt. 30, 1-2: 1 .

TörmäLÄ, T. 1977: Effects of mowing and ploughing on the primary production and flora and fauna of a reserved field in Central Finland. Acta Agric. Scand. 27: 253-264.

- \& RaAtikatnen, M. 1976. Primary production and seasonal dynamics of the flora and fauna of the field stratum in a reserved field in Middle Finland. J. Scient Agric. Soc. Finl. 48: 363-385.

Käsikirjoitus saapunut 29.12. 1978. 